Research Article

\title{
Chemical Characterization of Lauha Bhasma by X-Ray Diffraction and Vibrating Sample Magnetometry
}

\author{
Neetu Singh $^{*}$, K.R.C.Reddy ${ }^{1}$, N.K.Prasad ${ }^{2}$, Manjeet Singh $^{2}$
}

1. Associate Professor, Dept of Rasashastra, IMS, BHU;

2. Assistant Professor, Research Scholar, Department of Metallurgy, Institute of Technology, Banaras Hindu University, Varanasi, UP, 221005

\begin{abstract}
Herbomineral formulations are unique to Ayurveda. Lauha bhasma is an Ayurvedic metallic preparation used in iron deficiency anemia. Our emphasis in the present paper is on chemical characterization of Lauha bhasma at different steps by following X-ray Diffraction (XRD) study and Vibrating Sample Magnetometry (VSM) study. XRD study was conducted for the samples after Sthalipaka, $1^{\text {st }}$ Puta, $5^{\text {th }}$ Puta, $10^{\text {th }}$ Puta, $15^{\text {th }}$ Puta and $20^{\text {th }}$ Puta and VSM study was conducted for samples after $5^{\text {th }} 10^{\text {th }}$ and $20^{\text {th }}$ Puta. $\mathrm{Fe}_{3} \mathrm{O}_{4}$ and $\gamma-\mathrm{Fe}_{2} \mathrm{O}_{3}$ may be accepted as chemical characterization of Lauha bhasma in broader way as it has been explored in this project by applying more sophisticated analytical technique like XRD and VSM.
\end{abstract}

Key words: Herbomineral formulations, Lauha bhasma, XRD, VSM, $\gamma-\mathrm{Fe}_{2} \mathrm{O}_{3}, \mathrm{Fe}_{3} \mathrm{O}_{4}$

\section{Introduction}

Ayurvedic

Herbomineral formulations are unique in terms of their minimal dose, quick action, palatibility and wider therapeutic applicability. The metals and minerals are not used as such. They are subjected to some needful procedures called "pharmaceutical processes" which include shodhana, marana etc. which convert the raw drug into a suitable compound form.

Earlier, the quality of the herbomineral preparation was subjected to review, but the methods were very crude like for test of completion of finished bhasma procedures like rekhapurnata,

*Corresponding author:

Research Scholar, Department of Rasa

Shastra, Faculty of Ayurveda, Institute of

Medical Sciences, Banaras Hindu

University, Varanasi, UP - 221005

Ph.No: +919889638581

E-mail: singhneetu17@gmail.com varitara, nischandratva etc were performed. With technological development the patients or the physicians seek assurance for the quality, safety and efficacy of any medicine, especially for export in the western countries. Therefore, quality control for herbal preparations and bhasmas is essential as many of them contain chemical entity as $\mathrm{Cu}, \mathrm{Zn}, \mathrm{Fe}, \mathrm{As}$, $\mathrm{Hg}$ and $\mathrm{Pb}$. Current issue of quality control method of identification of compounds made up of various metals/ mineral requires chemical characterizations by XRD. At the same time to reveal the magnetic property of iron it is also required the Lauha bhasma to screen under VSM. Hence, in present paper observations of Lauha bhasma found in XRD \& VSM are mentioned.

Lauha bhasma an Ayurvedic preparation is one of the best medicines for iron deficiency anemia. It is better absorbed from GIT and is devoid of the side effects. Lauha bhasma is prepared by following steps of Samanya shodhana, 
Vishesha shodhana, Bhanupaka, Sthalipaka and Putapaka. Putapaka was conducted at a temperature of $550^{\circ} \mathrm{C}$ $600^{\circ} \mathrm{C}$ in electric muffle furnace. It took twenty puta (shown in Figure 01, 02, and 03) for complete conversion of material into finally prepared bhasma form (therapeutic form of material). The finally prepared bhasma was identified on physicochemical parameters. The physical parameters were colour (blackish redpakwajambu phala varna), rekhapurnatva (on rubbing the bhasma between index finger and thumb the minute particles entered into the furrows of finger), taste (the bhasma was found to be tasteless) and varitara (The bhasma was found approximately $75 \%$ varitar). The chemical parameter was apunarbhava (No lustrous particles seen which was indicative of absence of free metal in the bhasma).

Our emphasis in the present paper is on chemical characterization of Lauha bhasma at different steps by following Xray Diffraction (XRD) study and Vibrating Sample Magnetometry (VSM) study. To find the major phases present at different levels of pharmaceutical procedures is the main aim of conducting these tests.

In the process of samanya sodhana the iron turnings were heated till red hot and quenched (nirvapa) in different medias for seven times i.e. tila taila, takra, gomutra, kānji and kulattha kwātha simultaneously.( Ratna Samuchchya, 5/13)(1) For visesa sodhana the process of nirvapa in triphala kwatha was adopted and repeated for seven times. (Ratna Samuchchya, $5 / 102)(2)$ The process of marana was completed in three steps viz. bhanupaka, sthalipaka and putapaka. (Rasa Tarangini, 20/ 24, 28, 52)(3) In the process of bhanupaka the lauha churna procured after visesa sodhana was kept in sunlight along with triphala kwatha till complete drying. The process was repeated for seven times. Sthalipaka and Putapaka are specific heating methods. In Sthalipaka the material (iron turnings) was boiled along with triphala kwatha till drying and in the process of Puta the material was triturated with triphala kwatha and subjected to heating (at a temp. $550^{\circ} \mathrm{C}-600^{\circ} \mathrm{C}$ ) in electric muffle furnace.

XRD study was conducted for the samples after Sthalipaka, $1^{\text {st }}$ Puta, $5^{\text {th }}$ Puta, 10 ${ }^{\text {th }}$ Puta, $15^{\text {th }}$ Puta and $20^{\text {th }}$ Puta and VSM study was conducted for samples after $5^{\text {th }}, 10$ th and $20^{\text {th }}$ Puta.

\section{Materials \& Methods}

\section{X-Ray Diffraction:}

Principle: X-ray powder diffraction is most widely used non-destructive technique for investigation of structural properties of crystalline materials. X-ray diffraction is based on constructive interference of monochromatic X-rays and a crystalline sample.

Sample Preparation and Experimental: $200 \mathrm{mg}$ of sample was taken. Sample was grinded to fine powder. Powder less than $\sim 10 \mu \mathrm{m}$ (or 200-mesh) in size is preferred. The powder was mounted on sample holder and subjected for reading.

\section{Vibrating Sample Magnetometer}

Principle: A vibrating sample magnetometer (VSM) operates on Faraday's Law of Induction, which tells us that a changing magnetic field will produce an electric field. This electric field can be measured and can tell us information about the changing magnetic field. A VSM is used to measure the magnetic behavior of magnetic materials.

Experimental: The magnetic measurements ( $\mathrm{M}$ vs $\mathrm{H}$ ) of the powder samples (after 5, 10 and 20 Putas) were performed using a Vibrating sample magnetometer (VSM, Lakeshore, Model 7410 ) at $300 \mathrm{~K}$. The principle of VSM is the measurement of the electromotive force induced by magnetic sample when it is vibrated at a constant frequency in the presence of a static and uniform magnetic 
field. The VSM is operated up to $2 \mathrm{~T}$ at a vibration frequency of $82 \mathrm{~Hz}$. The magnetic moment was calibrated with standard sample of $\mathrm{Ni}$ which had known saturation magnetization $\left(\mathrm{M}_{\mathrm{S}}\right.$ of $6.92 \mathrm{emu}$ at $0.5 \mathrm{~T}$ ). A small amount of powder was weighed and tightly held in the sample holder to avoid movements inside the sample holder. The amount of sample was 17.6, 18.3 and $15.4 \mathrm{mg}$ for sample no. 7,8 and 10 (Fifth, Tenth and Twentieth Puta) respectively.(4)

\section{Observations \& Result:}

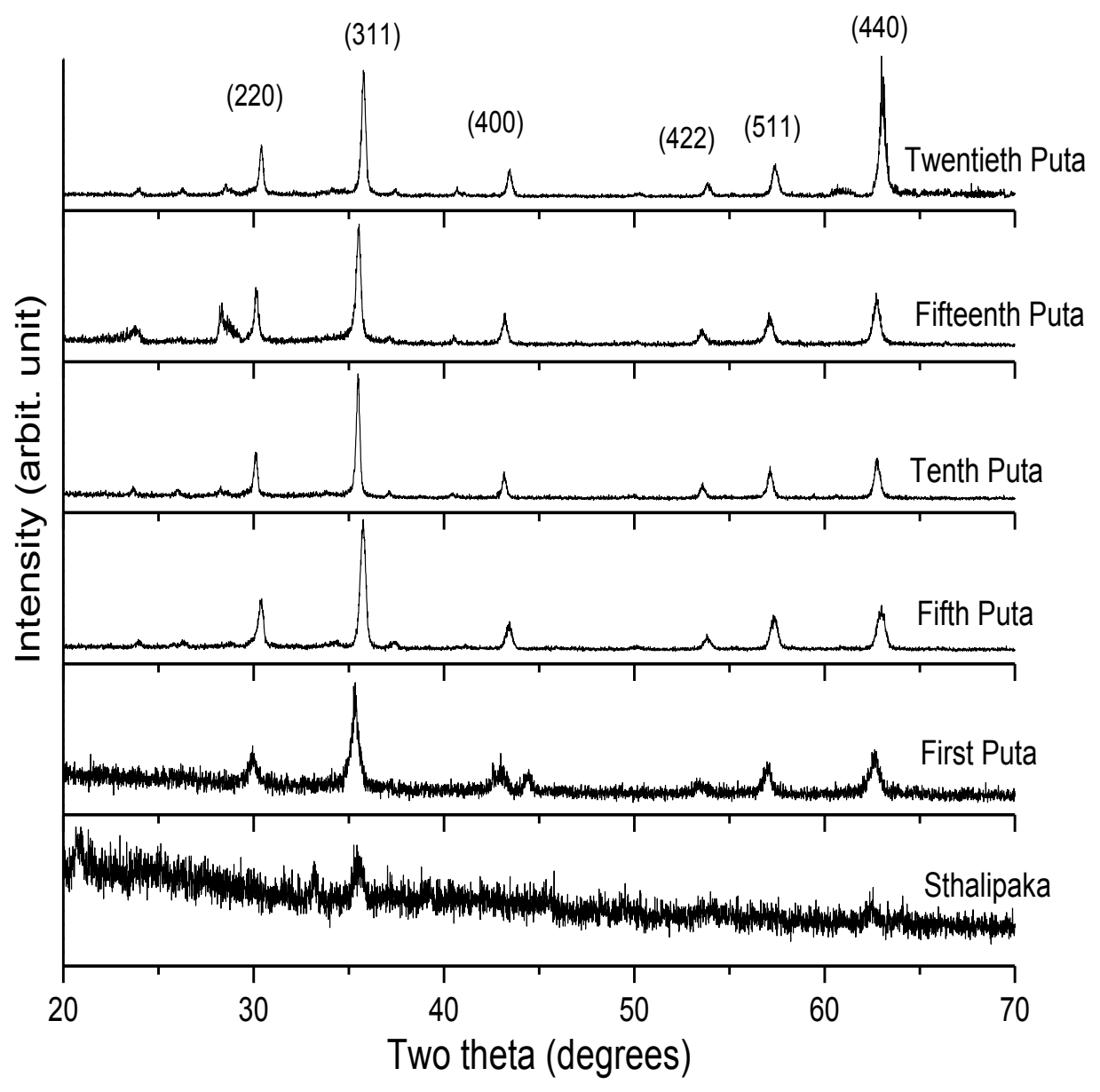

Fig1.1 : XRD pattern of all the samples

Fig.1.1: X-Ray diffraction of all the samples was done by Rigaku DMAX powder X-Ray diffractometer with $\mathrm{Cu}-\mathrm{K} \alpha$ radiation. XRD pattern is shown in Fig. 1 and the standard data was taken from ICDD-4+2007 version. Pattern indicates that crystallinity in the material increases successively from Sthalipaka to Twentieth
Puta because the intensity of the peaks is increasing continuously. The patterns reveal that the diffraction peaks corresponding to (220), (311), (400), (422), (511) and (440) planes of $\gamma-\mathrm{Fe}_{2} \mathrm{O}_{3}$ and $\mathrm{Fe}_{3} \mathrm{O}_{4}$ are present (ICDD PDF Card No. 00-001-1111 of $\mathrm{Fe}_{3} \mathrm{O}_{4}$ and Card No. 00-002-1047 of $\gamma-\mathrm{Fe}_{2} \mathrm{O}_{3}$ Annexure 1). 
Since the peak position for both the phases i.e. $\mathrm{Fe}_{3} \mathrm{O}_{4}$ and $\gamma-\mathrm{Fe}_{2} \mathrm{O}_{3}$ appears at approximately same two theta values, normal XRD can not distinguish between these two phases. In the entire pattern except the pattern corresponding to Twentieth Puta, the (311) plane peak is most intense peak which means that $\mathrm{Fe}_{3} \mathrm{O}_{4}$ phase is dominating phase. From the pattern it is seen that the intensity of the peak corresponding to (440) plane increases continuously from Sthalipaka to Twentieth Puta which may be due to the increasing proportion of $\gamma-\mathrm{Fe}_{2} \mathrm{O}_{3}$ in prepared sample because the intensity of (440) plane peak is most intense peak in the diffraction pattern of $\gamma-\mathrm{Fe}_{2} \mathrm{O}_{3}$ (PDF Card No. 00-002-1047). In the sample Twentieth Puta the intensity of the peaks corresponding to (440) plane and (311) plane is comparable to each other which indicates that $\mathrm{Fe}_{3} \mathrm{O}_{4}$ and $\gamma-\mathrm{Fe}_{2} \mathrm{O}_{3}$ may be present in approximately equal proportion.

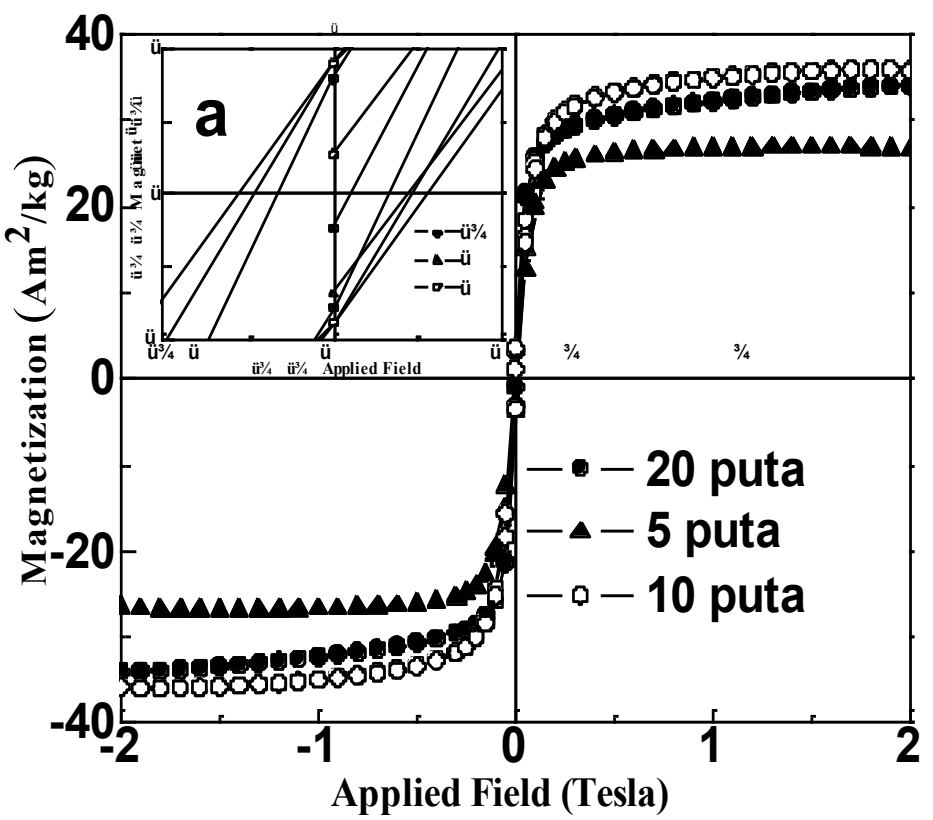

Fig 1.2. Hysteresis loops measured in VSM for different samples

Fig 1.2: Magnetic measurements suggest that all the three samples are magnetic in nature. There magnetization value was found to be 27,36 and $34 \mathrm{Am}^{2} / \mathrm{kg}$ at $2 \mathrm{~T}$ external field for the samples which were undergone $5^{\text {th }}, 10^{\text {th }}$ and $20^{\text {th }}$ Putas respectively. This suggests the samples are either magnetite $\left(\mathrm{Fe}_{3} \mathrm{O}_{4}\right)$ or maghemite $(\gamma$ $\mathrm{Fe}_{2} \mathrm{O}_{3}$ ). However, the lower value of the magnetization for these samples compared to the aforementioned magnetic iron oxides is because of the presence of the organic materials associated with the samples whose weight were also included while during the measurement. The increase in the magnetization value at higher Puta could be attributed to the decrease of organic materials which was added during intermediary pharmaceutical processes. The inset of the figure indicates that all three samples displayed hysteresis loop which suggest that these Lauha bhasmas are multi-domain.

\section{Discussion:}

$\mathrm{XRD}$ pattern is revealing that the crystallinity of material is increasing successively from Sthālipāka to $20^{\text {th }}$ Puta. In the sample after Sthälipāka no intense peak was observed which is revealing amorphous nature of material. At the level of Sthälipāka there is not complete oxidation of Lauha and due to incorporation of triphalā kwātha residues 
the material has got changed to amorphous mass.

In every sample, after further processing i.e. subjecting to Puta the peaks get intensified which are suggesting that iron is getting converted to a compound form that is iron oxide and thus converting the material to crystalline form which is showing intense peak.

In all the samples except $20^{\text {th }}$ Puta, the (311) plane peak is most intense peak which means that $\mathrm{Fe}_{3} \mathrm{O}_{4}$ is dominating phase. It is seen that peak corresponding to (440) plane increase continuously from Sthälipāka to $20^{\text {th }}$ Puta which may be due to the increasing proportion of $\gamma-\mathrm{Fe}_{2} \mathrm{O}_{3}$.

The above finding suggests that during further process of Puta the material gets oxidized and in the beginning the major phase is $\mathrm{Fe}_{3} \mathrm{O}_{4}$ but up to stage of finally prepared bhasma $\gamma-\mathrm{Fe}_{2} \mathrm{O}_{3}$ and $\mathrm{Fe}_{3} \mathrm{O}_{4}$ are in equal proportion.

The Vibrating Sample Magnetometry (VSM) study is also supporting the above finding of XRD. The VSM study was carried out of three samples i.e. after $5^{\text {th }}$ Puta, $10^{\text {th }}$ Puta and $20^{\text {th }}$ Puta.
The study suggests that all the three samples are magnetic in nature. The magnetization value was found 27, 36 and $34 \mathrm{Am}^{2} / \mathrm{Kg}$ at $2 \mathrm{~T}$ external field it means that the compound is either $\mathrm{Fe}_{3} \mathrm{O}_{4}$ (Magnetite) or $\gamma-\mathrm{Fe}_{2} \mathrm{O}_{3}$ (Maghemite).

\section{Conclusion:}

$\mathrm{Fe}_{3} \mathrm{O}_{4}$ and $\gamma-\mathrm{Fe}_{2} \mathrm{O}_{3}$ may be accepted as chemical characterization of Lauha bhasma in broader way as it has been explored in this project by applying more sophisticated analytical technique like XRD and VSM.

\section{References:}

1. Dattatrey Anant Kulkarni, Rasa Ratna Samuchchya of Rasa Vagbhatta, Vol1. New Delhi; Meharchand Lachhhmandas Publications; 1998; 93 \& 113.

2. Sharma Sadanand. Rasa Tarangini. $11^{\text {th }}$ Edition. Delhi; Motilal Banarasidas; 2004; 497, 498 \& 502.

3. http://Uweb.txstate.edu/ ab35/manuals /VSM/vsm.pdf. cited on 23 Oct. 2008.

\section{Abbreviations:}

$\begin{array}{lll}\text { XRD } & : & \text { X- Ray Diffraction } \\ \text { VSM } & : & \text { Vibrating Sample Magnetometry } \\ \mathrm{T} & : & \text { Tesla } \\ \text { ICDD } & : & \text { International Centre for Diffraction Data }\end{array}$




\section{ANNEXURE}

Table No.1.1: showing $2 \theta$ value and d-spacing of different samples and standard values from ICDD.

\begin{tabular}{|c|c|c|c|c|c|c|c|}
\hline \multicolumn{2}{|c|}{ S.No.7 (5 ${ }^{\text {th }}$ Puta $)$} & \multicolumn{2}{|c|}{ S.No.8 $\left(10^{\text {th }}\right.$ Puta $)$} & \multicolumn{2}{|c|}{$\begin{array}{l}\text { PDF Card No.00- } \\
\text { 001-1111 }\left(\mathrm{Fe}_{3} \mathrm{O}_{4}\right)\end{array}$} & \multicolumn{2}{|c|}{$\begin{array}{l}\text { PDF Card No.00- } \\
002-1047\left(\gamma \mathrm{Fe}_{2} \mathrm{O}_{3}\right)\end{array}$} \\
\hline $2 \theta$ & d space & $2 \theta$ & d space & $2 \theta$ & d space & $2 \theta$ & d space \\
\hline & & 23.67 & 3.756 & & & & \\
\hline & & 25.97 & 3.428 & & & & \\
\hline & & 28.22 & 3.16 & & & 35.7431 & 2.5100 \\
\hline 30.36 & 2.942 & 30.09 & 2.967 & 30.0634 & 2.9700 & 30.4837 & 2.9300 \\
\hline 35.72 & 2.512 & 35.4671 & 2.529 & 35.4512 & 2.5300 & 33.7963 & 2.6500 \\
\hline 37.36 & 2.405 & 37.10 & 2.421 & & & & \\
\hline 43.38 & 2.084 & 43.13 & 2.096 & 43.0368 & 2.1000 & 43.6923 & 2.0700 \\
\hline 53.83 & 1.702 & 53.57 & 1.709 & 53.5459 & 1.7100 & 54.2312 & 1.6900 \\
\hline 57.38 & 1.605 & 57.11 & 1.611 & 57.1665 & 1.6100 & 57.557 & 1.6000 \\
\hline 62.88 & 1.477 & 62.73 & 1.48 & 62.7262 & 1.4800 & 62.7262 & 1.4800 \\
\hline
\end{tabular}

Table No.1.2: showing two theta value and d spacing of different samples

\begin{tabular}{|c|c|c|c|c|c|c|c|}
\hline \multicolumn{2}{|c|}{$\begin{array}{c}\text { S.No.5 } \\
\text { (Sthalipaka) }\end{array}$} & \multicolumn{2}{c|}{ S.No.6 $\left(\mathbf{1}^{\text {st }}\right.$ Puta $)$} & \multicolumn{2}{c|}{ S.No.9 $\left(\mathbf{1 5}^{\text {th }}\right.$ Puta) } & \multicolumn{2}{c|}{ S.No.10 (20 } \\
\hline $\mathbf{2 \theta}$ & d space & $\mathbf{2 \theta}$ & d space & $\mathbf{2 \theta}$ & d space & $\mathbf{2 \theta}$ & d space \\
\hline & & & & 23.77 & 3.74 & 23.98 & 3.708 \\
\hline & & & & 28.23 & 3.159 & 26.22 & 3.396 \\
\hline & & 29.94 & 2.982 & 28.65 & 3.113 & 28.53 & 3.126 \\
\hline 30.01 & 2.975 & & & 30.12 & 2.965 & 30.38 & 2.94 \\
\hline 35.48 & 2.528 & 35.27 & 2.543 & 35.491 & 2.527 & 35.7521 & 2.509 \\
\hline & & 42.59 & 2.121 & & & 37.39 & 2.403 \\
\hline & & 43.06 & 2.099 & 40.50 & 2.225 & 40.66 & 2.217 \\
\hline & & 43.14 & 2.095 & 43.17 & 2.094 & 43.43 & 2.082 \\
\hline & & 44.37 & 2.04 & & & 44.79 & 2.022 \\
\hline & & & & 53.48 & 1.712 & 53.83 & 1.702 \\
\hline & & 56.98 & 1.615 & 57.08 & 1.612 & 57.35 & 1.605 \\
\hline 62.48 & 1.485 & 62.62 & 1.482 & 62.73 & 1.48 & 62.9979 & 1.474 \\
\hline
\end{tabular}




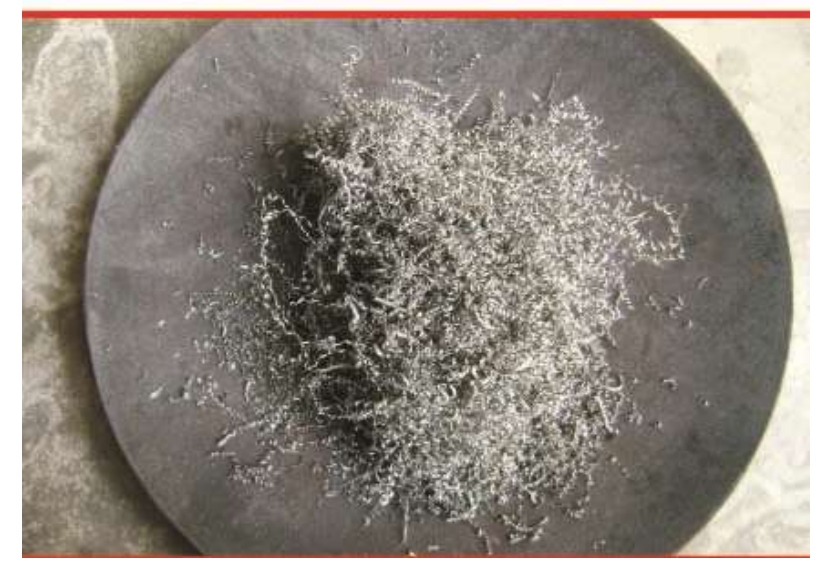

Figure 01: Raw material (iron turnings)

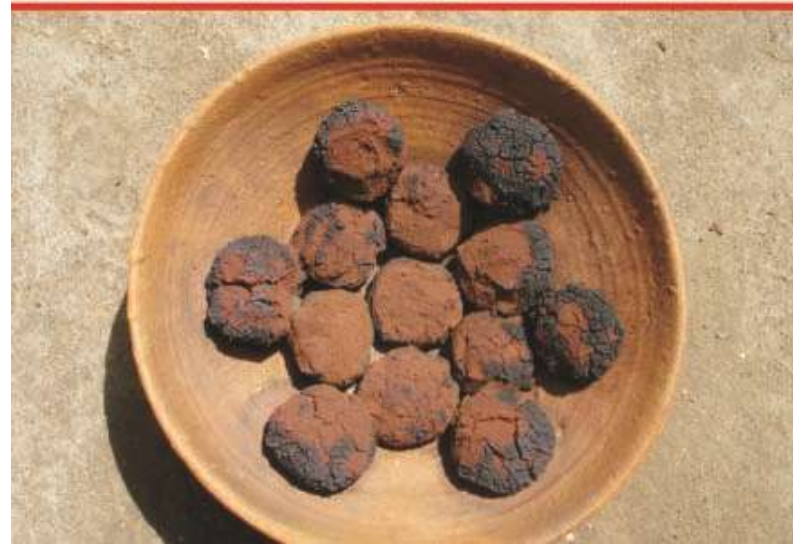

Figure 02: Pellets after $4^{\text {th }}$ Puta

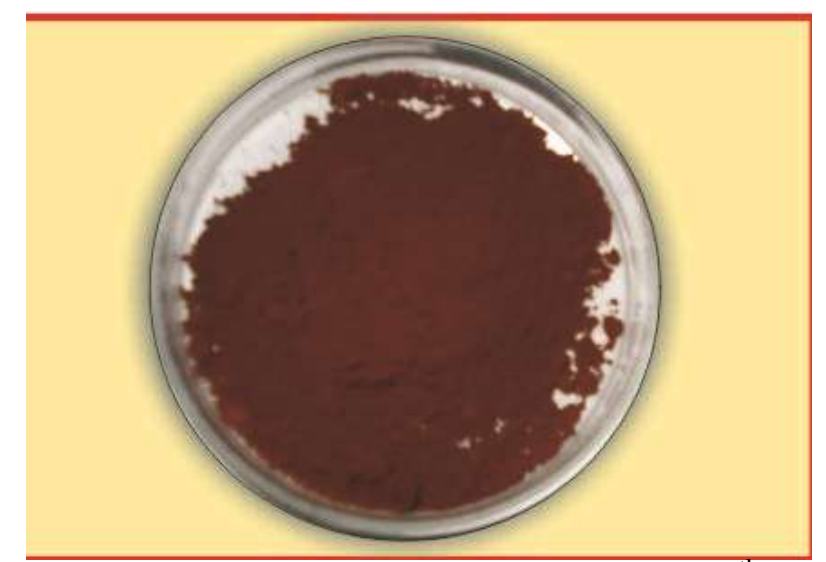

Figure 03: Finally prepared bhasma ( after $20^{\text {th }}$ Puta) 